\title{
Assessment of the Efficacy of Creativity-Based Instructional Model on Scientific Attitude in Basic Science and Technology Among Pupils
}

\author{
Joy C. Orji ${ }^{1}$, Celina S. Gana ${ }^{2}$, Victor S. Ezema ${ }^{3}$, Emmanuel C. Okenyi ${ }^{3}$, Christian S. Ugwuanyi ${ }^{4}$, Anthonia N. \\ Ngwoke $^{3}$, Florence E. Otta ${ }^{5}$, Alexander Chuwkuemeka Okondugba ${ }^{6} \&$ Julie U. Ibiam ${ }^{3}$ \\ ${ }^{1}$ Institute of Education, University of Abuja, Nigeria \\ ${ }^{2}$ Department of Science Education, School of Science and Technology Education, Federal University of \\ Technology, Minna, Nigeria \\ ${ }^{3}$ Department of Educational Foundations, University of Nigeria, Nsukka, Nigeria, Enugu State, Nigeria \\ ${ }^{4}$ Postdoctoral fellow, School of Education Studies, Faculty of Education, University of the Free State, \\ Bloemfontein, South Africa \\ ${ }^{5}$ Department of Educational Foundations, Ebonyi State University, Abakaliki, Nigeria \\ ${ }^{6}$ Dominican University, Ibadan, Oyo State, Nigeria \\ Correspondence: Christian S. Ugwuanyi, Postdoctoral fellow, School of Education Studies, Faculty of Education, \\ University of the Free State, Bloemfontein, 9300, South Africa. E-mail: ugwuanyics@ufs.ac.za
}

Received: February 9, 2020 Accepted: February 25, 2020 Online Published: March 11, 2020

doi:10.5539/gjhs.v12n5p1 URL: https://doi.org/10.5539/gjhs.v12n5p1

\begin{abstract}
This study assessed the efficacy of creativity-based instructional model on scientific attitude in Basic science and technology among pupils. The study adopted the quasi-experimental design of non-equivalent control group. A sample of 244 pupils ( 135 males and 109 females) was drawn for the study using a multistage sampling procedure. The instruments used for data collection was the Scientific Attitude Assessment Scale (SAAS). Data collected were analyzed using mean to answer the research questions and Analysis of Covariance (ANCOVA) to test the null hypotheses at 0.05 level of significance. The findings of the study revealed that creativity-based instructional model significantly enhanced pupils' scientific attitude. It was equally revealed that gender had no significant influence on pupils' scientific attitude. Based on the findings and conclusions, it was recommended among others, that the use of Creativity-based Instructional Strategy should be encouraged and popularized among primary school teachers through workshops, conferences and seminars.
\end{abstract}

Keywords: creativity-based instructional model, basic science and technology, scientific attitude

\section{Introduction}

For Nigerian children to develop scientific attitude and interest in science, the scientific attitude which is inherent in them should be kept aglow. Unfortunately, this has not been the case. Personal experience of the researcher as a classroom teacher and some research findings have shown that the development of scientific attitude and interest in Basic Science and technology have not been adequately promoted, probably due to lack of creativity by teachers of Basic Science and Technology in primary schools. It, therefore, means that effective learning of science at the primary school level cannot be achieved. According to Otuka and Uzoechi (2014), science is an attempt by human beings to organize their experiences about nature into a meaningful system of explanations. Benson and Egolum (2017) state that science subjects are disciplines that involve the systematic process of using observation and experiment to obtain a verifiable knowledge about nature and natural phenomena. This can be accomplished through technology which is more or less based on the principles of science.

Benson and Egolum defined technology as the science of mechanical and industrial arts which involves the application of science to solve human problems. Through technology, the know-how and creative process that utilize tools, resources and systems to solve a problem and enhance control over natural and artificial environments for the benefit of human are developed. As the foundation on which subsequent science subjects rest, primary science, in conjunction with technology, was integrated to become Basic Science and Technology (BST).Basic Science and Technology is a subject that infuses both science and technology required for problem-solving. 
No doubt, Basic Science and Technology (BST) integrates both science and technology at the primary school level with well-defined objectives. Adeniyi (2007) outlined the objectives of the BST curriculum as; to enable the learner develop interest in science and technology and acquire basic knowledge and skills in science and technology; to enable learners to apply their scientific and technological knowledge to meet societal needs; to enable them take advantage of numerous career opportunities offered by science and technologies and lastly, to enable the learners to become prepared for further studies in science and technology.

On the other hand, continuous failure in a subject can make pupils develop an unfavourable or negative attitude towards a subject and vice versa (Olowojaiye, 2000). Newbill (2005) observed that attitudes serve functions which include social expressions, value expression, utilitarian and dispositional functions for people that hold them. In the same vein, Narmadha and Chamadeswari (2013) define attitude as a hypothetical construct that represents an individual's degree of like or dislike for something. They went further to explain that attitudes are generally positive or negative views of a person towards a place, thing or event. In his opinion, Harsimrandeep (2013) defines attitude as a disposition which people hold about themselves, other people, object and issues. Ali and Awan (2013), believe that attitudes towards a subject determine success in that subject. It could, therefore, be inferred that favourable attitude results in good achievement in a subject while negative attitude could lead to failure.

However, Gross (2016) observed that people can be ambivalent towards an object which means that one can simultaneously exhibit both positive and negative attitudes depending on the context of the situation. Besides the general attitude which is dispositional, there are also other aspects of attitude like scientific attitude that can affect learning outcomes. Scientific attitude could be regarded as attributes or traits of scientists. These natural traits include; honesty, curiosity, open-mindedness, suspended judgment, ability to hypothesize and experiment (Harlene, 2010). In line with this opinion, Mukhopadhyay (2014) defines scientific attitude as inherent traits of a typical scientist which include honesty, curiosity, open-mindedness, suspended judgment, ability to hypothesize and experiment. On the other hand, Lucap (2015) had stated that positive scientific attitude in children needs to be encouraged to sustain creativity among pupils at the basic level of education. However, it becomes worrisome that one of the major challenges of science education at the basic education level is how to enhance the scientific attitude of the pupils through creative, functional and active learning.

It is, therefore, the contention here that the application of Creativity-based instructional model could make a significant contribution to the development of pupils' scientific attitude. Besides, the scientific attitude of pupils may vary by gender. The term gender is used to signify all those characteristics or features that a person demonstrates to identify himself or herself as having the status of boy or man, girl or woman, respectively. Indicators of such a role include styles of clothing, speech patterns, movement, occupations, and other factors restricted to a particular biological sex. Gross(2016) defines gender as behaviours, attitudes, values which a particular society either expects from or considers appropriate to male and females based on their biological sex. Each society has its own prescription for how men and women ought to behave.

Many studies which have been conducted showed gender as having a significant influence on the learning outcomes of learners. These studies include those of Brickhouse and Potter (2001); Jegede (2007), Okereke and Onwuka (2011); Ukozor (2011); Zembar and Blume (2011); and Olasehinde and Olatoye (2014) thereby making gender a salient variable that needs to be incorporated in the present study. As a matter of fact, it has been found that there are some aspects of science that interest girls and those that are interesting to boys. Gender differences deepen from primary school level to secondary schools in most countries and have been maintained over time. Brickhouse and Potter (2001) found out that male students are interested in topics such as atomic bombs, atoms, computers and scientific application in technology such as application in mechanics in cars.

On the other hand, girls are mainly interested in topics such as animal communication, healthy diets and topics related to aesthetic dimension such as rainbows while their typical out-of-school science-related experiences are bread-making, observing birds and stars, knitting, planting seeds. It is possible therefore that these gender-related experiences in science at primary school level could influence scientific attitude and interest in Basic Science and technology using a creativity-based approach. It, therefore, implies that functional science education could be strengthened through creativity. According to Bruce (2004), creativity is defined as what brings into existence new ideas; independent and original ways of doing things and new creation of all kinds. In essence, new and imaginative ideas are turned into reality. For creativity to be made active, it has to be hinged on the process of original ideas through exploration, discovery and interactions within the classroom setting. Antonious, Georgios, Constantine and Lopes (2016), believe that teachers' creativity in the classroom could manifest in such behaviours as; accepting unusual ideas, accepting unusual questions from pupils; providing opportunities including materials for enhancing curiosity, imaginative activities, showing the learners that their ideas have values, improvising 
materials and providing opportunities for learners to explore the environment.

Studies have been conducted on the effectiveness of innovative teaching methods on pupils' scientific attitudes. Salman, Ayinla, Adeniyi, Ogundele, and Ameen (2012) found that primary school pupils' attitude towards mathematics was significantly better when exposed to problem-solving instructional strategy than the conventional teaching strategy. The study also found that there was a significant difference in the attitude of male and female pupils towards mathematics. Mohammad, Ebrahim, Dehghani and Rezaei (2012) revealed that most pupils had a positive attitude towards science and technology. The results also showed that there was a significant difference between males and female pupils' attitude towards science and technology in favour of males. Chebii (2015) revealed that primary school pupils who were taught by the mastery approach performed better than those who were taught by the conventional method. Jebson and Hena (2015) found a significant effect of gender on the attitude of pupils towards science in favour of the males.

Based on the foregoing, therefore, the researchers conducted this study to assess the efficacy of creativity-based instructional model on scientific attitude in Basic Science and Technology among pupils. The questions posed for the research are:

1. What is the effect of the creativity-based instructional model on pupils' scientific attitude in Basic Science and Technology?

2. What is the influence of gender no pupils' scientific attitude in Basic Science and Technology?

The researchers hypothesized that:

1. The creativity-based instructional model had significant $(p<.05)$ on pupils' scientific attitude in Basic Science and Technology.

2. Gender has no significant influence on pupils' scientific attitude in Basic Science and Technology.

\section{Materials and Methods}

The design of the study is quasi-experimental. Specifically, the non- equivalent control group design was used. In this design, research participants were not randomly assigned to the experimental and control groups, and both groups took a pretest and a posttest (Gall, Gall, \& Borg, 2007). The study was conducted in Gwagwalada area council of the Federal Capital Territory Abuja (FCT). Gwagwalada is one of the area councils in the FCT Abuja which is made up of rural and urban areas.

\subsection{Participants}

The sample used for the study consisted of 244 primary school pupils in class five (135 males and 109 females) drawn from four co-educational primary schools in Gwagwalada area council, Abuja. The multistage sampling procedure was used to draw the sample. In the first stage, a simple random sampling technique was used to draw four out of 73 primary schools in Gwagwalada area council. Specifically, Hat-and-Draw method was used. The researcher wrote the name of each school on a slip of paper, folded and put into a container. After a thorough reshuffling, the researcher dipped her hand and picked one slip. The researcher unfolded the slip and recorded the name of the school written on it. After recording the name of the school that was picked, the same slip was folded and put back into the container. This process was repeated until all the four schools were drawn. Using the Hat-and-Draw method, four schools were drawn. Out of the schools, two schools were randomly assigned to experimental and control groups respectively. One intact class in each of the four schools was used for the study. 


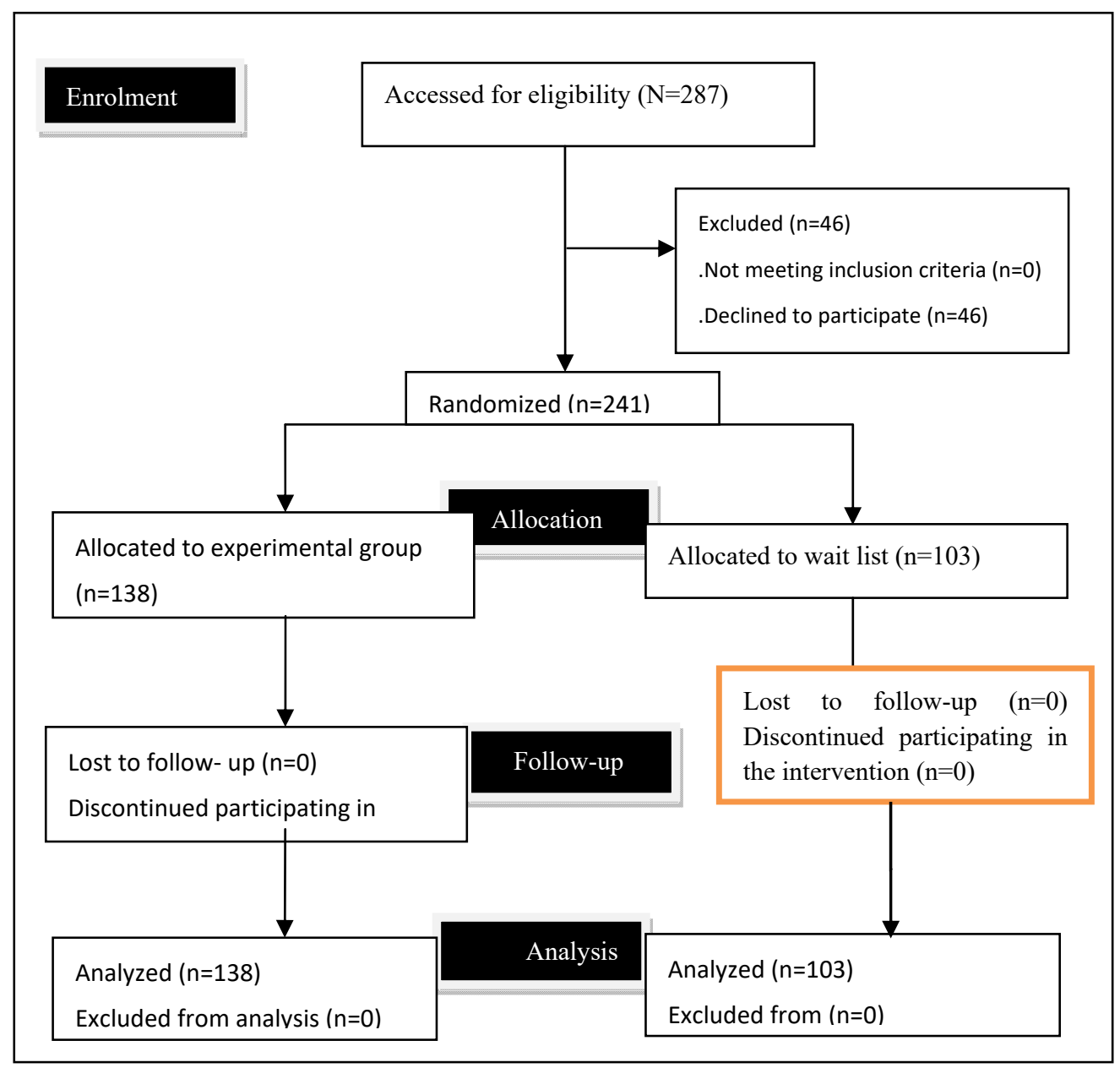

Figure 1. Flow diagram for Participants Allocation

\subsection{Measure}

Scientific Attitude Assessment Scale (SAAS). SAAS is a 22-item instrument was designed to measure the pupils' scientific attitude towards BST before and after the treatment. The instrument was adapted from a standardized scientific attitude test called Test of Science-Related Attitude (TOSRA) with a reliability coefficient of 0.84 developed by Fraser (1982). From the original instrument, some items were identified as culture-loaded with a foreign background. The TOSRA was designed to elicit responses in line with a modified Likert-type four-point scale of Very much Agree (VMA)-4, Simply Agree (SA)-3, Simply Disagree (SD)-2 and Very much Disagree (VMD)-1. The instrument was face validated by experts in measurement and evaluation as well as Childhood education. The internal consistency reliability coefficient of the items of the SAAS was estimated to be 0.85 using Cronbach Alpha method.

\subsection{Treatment Procedure}

First, the researcher personally visited the selected schools and sought permission from the headmasters to use primary 5 pupils. On this occasion too, information was collected on the number of arms of primary 5 classes and the number of pupils in each class. Before the commencement of treatment, both instruments were administered as pretests and the scores recorded. The major treatment for the study was done using the Creativity-based instructional model (for the experimental group) which was anchored on introduction, cooperation, praises and commendation, accommodation of unusual questions, class activities and evaluation. During the introduction, the teacher introduced the lesson by presenting the instructional materials to pupils and asked them relevant questions that linked their previous knowledge with the topics of the day. Although the pupils gave diverse views and answers, the teacher accommodated and appreciated them by instructing the pupils to clap for themselves. The teacher addressed the answers the way they came depending on pupils' conception of the questions. 
The next stage involved the teacher explaining the instructional material to present the lesson to the pupils. The pupils listened as the teacher made the explanations to them, then the teacher wrote out those things on the board which the pupils copied. In the course of the lesson, the teacher asked the pupils questions which they also gave different and unusual answers. The teacher accommodated and appreciated all the answers by encouraging them to clap for themselves especially when the answers were coming from their own perspectives. The teacher then connected and harmonized all their responses into a more realistic answer. One major observation here was that the teacher did not condemn any question or portray their responses in a bad light no matter how wrongly framed or worded by the pupils.

The teacher then shared the pupils into groups and engaged the pupils in activities based on the topic using the instructional materials. The teacher asked the pupils to state or mention their observations or findings. At this juncture, the teacher encouraged and accommodated unusual responses or ideas that come from pupils on what they observed. The teacher then harmonized all their ideas which might not even conform to the topic. The teacher encouraged and appreciated all. Towards the end of the lesson, the teacher then evaluated the lesson by asking questions based on the objectives of the lesson

The treatment lasted for five weeks. The experimental group was taught the following concepts: water pollution, air pollution, waste and waste disposal using the Creativity-based teaching strategy. The control group was taught the same concepts using the conventional method. The data collection was done in such a way that the pupils did not know that they were being used as subjects in research. The fact was deliberately hidden from them in order to avoid the possibility of the pupils presenting artificial behaviours that they would not have exhibited in a natural teaching situation.

At the end of the five weeks, both the SAAS was re-administered as posttests. The tests were administered to both groups at the same time and under the same testing conditions. At the end of the test administration, the instrument was collected and counted. The information obtained was subjected to data analysis.

\subsection{Analysis}

The research questions were answered using mean and standard deviation. The null hypotheses were tested at 0.05 level of significance using Analysis of Covariance (ANCOVA). Again, pretest scores were used as a covariate and therefore helped to establish the homogeneity or equivalence of the two groups before the treatment. Furthermore, the ANCOVA helped to control for the errors arising from initial differences as a result of non-randomization of the intact classes.

\section{Results}

Table 1. Mean analysis of the pretest and posttest scientific attitude scores of pupils taught Basic Science and Technology using the creativity-based instructional model (CBI) and those taught using the conventional method

\begin{tabular}{llccccc}
\hline Variable & & \multicolumn{3}{c}{ Pre-test } & \multicolumn{2}{c}{ Post-test } \\
\cline { 3 - 6 } Teaching Methods & N & $\bar{X}$ & SD & $\bar{X}$ & SD & \\
\hline CBI Model & 138 & 34.91 & 1.82 & 58.70 & 3.50 & 23.79 \\
Conventional Method & 103 & 34.50 & 1.83 & 46.49 & 3.79 & 11.99 \\
\hline
\end{tabular}

Result in Table 1 shows the effect of the creativity-based instructional model on pupils' scientific attitude. The result shows that pupils taught Basic Science and Technology using the creativity-based instructional model (experimental group) had a pretest scientific attitude mean score of 34.91 with a standard deviation of 1.82 and a posttest mean of 58.70 with a standard deviation of 3.50. The mean gain or difference between the pretest and posttest means was 23.79 . On the other hand, pupils taught using the conventional method (control group) had a pretest scientific attitude mean score of 34.50 with a standard deviation of 1.83 and a posttest mean of 46.49 with a standard deviation of 3.79. The mean gain or difference between the pretest and posttest means was 11.99. For both groups, the scientific attitude mean scores of the pupils in the posttest were greater than that of the pretest, with those taught using the creativity-based instructional model (experimental group) having a higher mean gain than those taught using the conventional method (control group). Thus, the creativity-based instructional model appears more effective in promoting pupils' scientific attitudes than when taught using the conventional method.

$\mathbf{H}_{01}$ : There is no significant effect of Creativity-based instructional model on pupils' scientific attitude. 
Table 2. Analysis of Covariance (ANCOVA) of the effect of Instructional models on pupils' Scientific attitude

\begin{tabular}{|c|c|c|c|c|c|c|c|}
\hline Source & $\begin{array}{l}\text { Type III Sum of } \\
\text { Squares }\end{array}$ & df & Mean Square & $\mathbf{F}$ & Sig. & $\begin{array}{l}\text { Partial } \\
\text { Squared }\end{array}$ & Eta \\
\hline Corrected Model & $9397.118^{\mathrm{a}}$ & 4 & 2349.279 & 217.675 & .000 & .787 & \\
\hline Intercept & 376.946 & 1 & 376.946 & 34.926 & .000 & .129 & \\
\hline PreSAAS & 416.739 & 1 & 416.739 & 38.613 & .000 & .141 & \\
\hline Group & 8144.997 & 1 & 8144.997 & 754.685 & .000 & .762 & \\
\hline Gender & 42.687 & 1 & 42.687 & 3.955 & .058 & .016 & \\
\hline Group * Gender & 16.455 & 1 & 16.455 & 1.525 & .218 & .006 & \\
\hline Error & 2547.048 & 236 & 10.793 & & & & \\
\hline Total & 701265.000 & 241 & & & & & \\
\hline Corrected Total & 11944.166 & 240 & & & & & \\
\hline
\end{tabular}

a. R Squared $=.787$ (Adjusted R Squared $=.783$ ).

Result in Table 2 shows that there was a significant effect of Creativity-based instructional model on primary school pupils' scientific attitude, $F(1,236)=754.685, p<.05$. Also, the $\eta_{p}^{2}$ (partial eta squared) value of 0.76 showed that Creativity-based instructional model accounted for about 76 per cent improvement in pupils' scientific attitude.

Table 3. Pretest and posttest mean scores of male and female pupils on scientific attitude

\begin{tabular}{llccccc}
\hline Variable & \multicolumn{5}{c}{ Pre-test } & \multicolumn{5}{c}{ Post-test } & \multirow{2}{*}{ Mean Gain } \\
\cline { 2 - 5 } Gender & $\mathbf{N}$ & $\bar{X}$ & SD & $\bar{X}$ & SD \\
\hline Male & 109 & 34.81 & 2.11 & 53.62 & 7.57 & 18.81 \\
Female & 132 & 34.67 & 1.57 & 53.36 & 6.62 & 18.69 \\
\hline
\end{tabular}

Result in Table 6 shows the influence of gender on pupils' scientific attitude. The result shows that the scientific attitude mean score of male pupils at pretest was 34.81 with a standard deviation of 2.11 while the posttest mean was 53.62 with a standard deviation of 7.57. The mean gain or difference between the pretest and posttest means of male pupils was 18.81. On the other hand, the scientific attitude mean score of female pupils at pretest was 34.67 with a standard deviation of 1.57 while the posttest mean was 53.36 with a standard deviation of 6.62 . The mean gain or difference between the pretest and posttest means of female pupils was 18.69. For both male and female pupils, the scientific attitude mean scores at posttest were greater than that of the pretest. However, that of male pupils was slightly higher than that of the females. This, therefore, implies that gender had little influence on pupils' scientific attitude in favour of the male than female pupils.

$\mathbf{H}_{\mathbf{0 2}}$ : There is no significant influence of gender on pupils' scientific attitude

Result in Table 2 also showed that there was no significant influence of gender on pupils' scientific attitude, $F$ (1, 236 ) $=3.955, p=.058$. Additionally, the $\eta_{p}^{2}$ (partial eta squared) value of 0.02 indicated that $2 \%$ changes in pupils' scientific attitude were accounted for by the influence of gender.

\section{Discussion of the Findings}

The study findings have shown that Creativity-based instructional model appears more effective in promoting pupils' scientific attitudes than when taught using the conventional method. The study further found that there was a significant effect of Creativity-based instructional model on pupils' scientific attitude. This is to say that pupils who are taught Basic Science and Technology following the Creativity-based instructional model are more likely to develop more positive scientific attitude than those taught with the conventional instructional methods. The findings of this study under this variable have two-pronged insights to highlight, namely: That CBIM appears more effective in promoting pupils' scientific attitude than when taught using conventional method and that there is a notable significant effect on scientific attitude development in pupils taught using CBIM. These findings are both exciting and welcome. They are exciting because of the insight which they offer. This has found an association in 
the studies by Mohammad, Ebrahim, Dehghani and Rezaei (2012) who reported that most pupils taught using this method had a positive attitude towards science and technology. These findings are also welcome as they seem to aver more strongly as demonstrated from the works of Ibole (2000)and Chepkori (2013) who found out that pupils who were taught using conventional method did not just exhibit poor scientific attitude but also that their attitude towards science was negative to a very large extent.

Indeed, as if by way of trying a different approach, Orji (2006) who used the conventional method of chalk and talk had concluded that pupils' attitude towards primary science improved significantly after exposure to Modelling Instructional Strategy; a conclusion that further aligns itself with the findings of the present study. In the same vein, Sadi and Cakiroglu (2011) corroborate along this line by noting that hands-on activity enriched instruction was more effective in improving students' attitudes toward science than the traditional instructional method and that the effect was statistically more significant. By whatever standard one may use to measure the ability of Creativity-based Instructional Model(CBIM) to enhance scientific attitude seems to lie in the offer of opportunity for active participation; an opportunity unfolded for the pupils to observe, explore, generate new ideas, knowledge and develop new scientific skills on their own. This is all it takes to build in them with the much needed self-confidence.

One of the findings of this study is that gender had little influence on pupils' scientific attitude in favour of the male than female pupils. It was further proven through ANCOVA analysis that there was no significant influence of gender on pupils' scientific attitude. This could mean that the observed difference in the mean scientific attitude scores of male and female pupils was due to chance error. Thus, gender had no statistically significant influence on the pupils' pupils' scientific attitude. This finding is similar to that of Ibole (2000) who found that there was no significant difference in the attitude of male and female pupils towards science and scientific activities. The finding also corroborates with that of Etim (2002) that found no significant difference between the attitude of male and female pupils towards science learning.

Still, in line with the finding, Orji (2006) also reported no statistically significant difference between the mean attitude scores of male and female pupils towards primary science. Other researchers who obtained similar findings include Hatice (2012) whose study indicated that there was no significant influence of gender on pupils' attitude toward science subject and Olasehinde and Olatoye (2014) who found no significant difference between the attitude of male and female students towards science. Likewise, Olagunju and Babayemi (2014) found that there was no significant main effect of gender students' attitude towards basic science. Moreover, the finding is in line with the finding by Fatoba and Aladejana (2014), that gender did not affect students' attitude towards physics. The direction of these findings, in essence, shows that being a male or female may not be a strong determinant of pupils' scientific attitude or attitude to sciences.

On the contrary, the finding disagrees with those of Gail, Melissa, and Ann (2011) who found a significant gender difference in students' attitudes towards science, and Mohammad, Ebrahim, Dehghani and Rezaei (2012) who found that there was a significant difference between males and female pupils' attitude towards science and technology in favour of the males. Also, the finding contradicts that of Salman, Ayinla, Adeniyi, Ogundele, and Ameen (2012) that a significant difference exists between the attitude of male and female pupils towards mathematics. Similarly, Oluwatelure (2015) discovered that there was a significant effect of gender on the attitude of pupils towards science, the same with Jebson and Hena (2015) who found that there exists a significant effect of gender on the attitude of pupils towards science in favour of the males. This means that male students had a more positive attitude towards science subjects than their female counterparts. However, this study found no significant influence of gender on primary school pupils' scientific attitude. This implies that both male and female pupils could exhibit similar scientific attitude.

\section{Conclusion}

The creativity-based instructional model is very effective in improving the pupils' scientific attitude than the conventional method. On the other hand, gender had no significant influence on pupils' scientific attitude. The implication of the findings that creativity-based instructional model needs to be adopted by teachers when teaching Basic Science and Technology for possible improvement of pupils' scientific attitude. In other words, pupils' scientific attitude is likely to be boosted to a large extent if teachers can adopt a creativity-based instructional model when teaching Basic Science and Technology. Based on these, therefore, the researchers recommended that;

1) Primary school teachers should be encouraged through publications, seminars and conferences to adopt a creativity-based instructional model in the teaching of Basic Science and Technology to sustain pupils' scientific attitude. 
2) Curriculum developers should consider infusing the important elements of creativity into curriculum during the process of curriculum development.

\section{Acknowledgements}

The researchers acknowledged primary school pupils and their teachers for their esteemed cooperation during the conduct of the research.

\section{Competing Interests Statement}

The authors declare that there are no potential conflicts of interest.

\section{References}

Adeniyi, E. O. (2007). Nine-year Basic Education Curriculum: Basic Science \& Technology. Abuja: Nigeria Educational Research \& Development Council (NERDC)

Ali, M. S., \& Awan, A. S. (2013). Attitude towards science and its relationship with achievement in science. Interdisciplinary Journal of Contemporary Research, 4(10), 707-719.

Antonious, L., Georgios, N. Y., Constantine, A., \& Lopes, P. (2016). Can Computers foster Human Users' Creativity? Theory and Praxis of Mixed initiative Co-creativity. Digital Culture \& Education, 8(2), 136-153.

Benson, I. I., \& Egolum, E. O. (2017). Strategies for making science, technology and mathematics (STM) education accessible to all citizens. Science Teachers Association of Nigeria 60th Annual Conference Proceedings, 8- 9.

Bruce, T. (2004). Cultivating Creativity. London: Hodder\& Stoughton.

Brickhouse, N. W., \& Potter, T. (2001).Young women's scientific identity formation in an urban context. Journal of Research in Science Teaching, 38, 965 -980. https://doi.org/10.1002/tea.1041

Chebii, R. J. (2015). Effectiveness of science process skills mastery learning approach on secondary school students' achievement and acquisition of selected chemistry practical skills in KOIBATEK District schools, Kenya (An Unpublished M.Ed thesis of the University of Egerton, 1-64).

Chepkorir, S. (2013). The impact of students' attitudes on the teaching and learning of chemistry in secondary schools in Bureti District, Kenya. Journal of Emerging Trends in Educational Research and Policy Studies, 4(4), 618-626 .https://doi.org/10.3926/jotse.118

Etim, J. M. (2002). Students' perceptions of their science teachers and science teaching in Abaji Education Zone of the Federal Capital Territory of Nigeria (An unpublished M.EdDissertation,University of Abuja, Abuja, Nigeria).

Fatoba, J. O., \& Aladejana, A. L. ( 2014). Effects of gender on students' attitude to physics in secondary schools in Oyo state, Nigeria. European Scientific Journal, 10(7), 1457-1466.

Gall, M. D., Gall, J. P., \& Borg, W. R. (2007). Educational Research, An Introduction (8th ed.). Pearson International Edition, United States of America, 416.

Gail, M. J., Melissa, J. R., \& Ann, H. (2011).Gender differences in students' experiences, interests, and attitudes toward science and scientists (University of North Carolina at Chapel Hill, Chapel Hill, NC 27599-3500, USA Science Education Consultant, Raleigh, NC, USA).

Gross, R. (2016). Psychology: The Science of Mind and Behaviour. London: Hodder Education Press.

Hatice, B. C. (2012). Students' Attitudes toward School Chemistry: The Effect of Interaction between Gender and Grade Level. Asia-Pacific Forum on Science Learning and Teaching, 13(1), 62-78.

Harlene, W. (2010). Principles and Big Ideas of Science Education. Hartifield: Association for Science Education.

Harsimrandiep, S. G. (2013). Ethical Behaviour of sales staff towards consumers: A case study of service sector (Master's degree dissertation, Punjabi Agricultural University, Ludhiana).

Ibole, P. M. (2000). Using students perceptions of science teachers and the teaching of science as an index for enriching science instructions. Journal of Science Teachers of Nigeria, 42(18), 87-92.

Jebson S. R., \& Hena, A. Z. (2015). Students' attitude towards Science subjects in senior secondary schools in Adamawa state, Nigeria. International Journal of Research in Applied Natural and Social Sciences, 3(3), 117-124.

Jegede, S. A. (2007). Student's anxiety towards learning of chemistry in some Nigerian secondary schools. 
Education Research and Review, 2(7), 193-197.

Lucap, M. (2015). The scientific attitude of students major in sciences in the new teacherEducation curriculum. Asia Pacific Journal of Multidisciplinary Research, 3(5), 7-15.

Mohammad, N., Ebrahim, E., Aazam, D., \& Maryam, R. (2012).Students' attitude towards science and technology. Interdisciplinary Journal of Contemporary Research in Business, 3(10), 129-134.

Mukhopadhyay, R. (2014). Scientific attitude: Some psychometric considerations. Journal of Humanities and Social Sciences, 19(1), 98-100. https://doi.org/10.9790/0837-191798100

Narmadha, U., \& Chamundeswari, S. (2013). Prediction of attitude and interest of science students of different ability on their academic performance in basic science. International Journal of Sociological Research, 4(2), 68-72. https://doi.org/10.5296/jsr.v4i2.3910

Newbill, P. L. (2005). Instructional strategy to improve women attitudes towards science (Unpublished Dissertation), Blacksburg State University. Blacksburg.

Okereke, C., \& Onwuke, E. O. (2011). Influence of gender school location and the use of play-simulation on school achievement in chemistry. Retrieved from www.google.com

Olasehinde, K. J., \& Olatoye, R. A. (2014). Comparison of male and female secondary school students' learning outcomes in science in Kastina state, Nigeria. Mediterranean Journal of Social Science, 5(2), 517-523. https://doi.org/10.5901/mjss.2014.v5n2p517

Olasehinde, K. J., \& Olatoye, R. A. (2014). Scientific Attitude, Attitude to Science and Senior Secondary School Students in Katsina State, Nigeria. Journal of Educational and Social Reserach, 4(1), 445-553. https://doi.org/10.5901/jesr.2014.v4n1p445

Oluwatelure, T. A. (2015). Gender difference in achievement and Attitude of PublicSecondary School Students towards Science. American Journal of Educational Research, 6(2), 87-92.

Orji, A. B. C (2006). An examination of Potency of Modeling instructional strategy in Enhancing students' performance in Integrated Science. The Nigerian Academic Forum, 4(2), 177-180.

Otuka, J. O. E., \& Uzoechi, B. C. (2009). History and Philosophy of Science. OnaiviPrinting \& Publishing Co. Ltd Keffi, Nassarawa State, Nigeria.

Sadi, Ö., \& Cakiroglu, J. (2011). Effects of hands-on activity enriched instruction on students' achievementand attitudes towards science. Journal of Baltic Science Education, 10(2), 87-97.

Salman, M. F., Ayinla, J. O., Adeniyi, C. O., Ogundele, L. O., \& Ameen, S. L. (2012). Effect of problem-solving instructional strategy on senior secondary school students' attitude towards Mathematics in Ondo, Nigeria. International Journal of Asian Social Science, 2(7), 1056-1066.

Ukozor, F. I. (2011). Effect of Constructivism Teaching Strategy on Senior Secondary School Students Achievement and self-efficacy in Physics .African Journal of Science Technology and Mathematics Education, 1(1), 141-160.

Zembar, M. J., \& Blume, L. B. (2011). Gender and academic achievement. Prentice Hall.

\section{Copyrights}

Copyright for this article is retained by the author(s), with first publication rights granted to the journal.

This is an open-access article distributed under the terms and conditions of the Creative Commons Attribution license (http://creativecommons.org/licenses/by/4.0/). 